\title{
Modernistów sprawy najbardziej zagadkowe. Là-bas Jorisa-Karla Huysmansa i Wampir Władysława Stanisława Reymonta
}

The Most Mysterious Matters of the Modernists. Joris-Karl Huysmans' Là-bas and Władysław Stanisław Reymont's Wampir

Streszczenie: W artykule autorka zestawia dwie ważne modernistyczne powieści: Là-bas Jorisa -Karla Huysmansa (1891) i Wampira Władysława Stanisława Reymonta (1911). Z pozoru odległe i zupełnie różne, utwory te ujawniają jednak pokrewieństwo motywów i idei. Zarówno w Là-bas, jak i w Wampirze akcja toczy się w psychice głównych bohaterów, a świat przedstawiony stanowi $\mathrm{w}$ istocie odbicie ich duszy. Ważnym kontekstem analizy obu powieści jest nowoczesność, która determinuje wszystkie warstwy utworów. W przypadku Wampira walory literackie tekstu obniża brak dystansu Reymonta wobec zjawisk nadprzyrodzonych, które fascynują jego bohatera. Jeżeli chodzi o Là-bas, to Huysmans, choć sam zainteresowany ezoteryką, potrafi zdobyć się na konieczny dla autora dystans, co przekłada się na dużą wartość jego powieści. W obu książkach fascynacja zjawiskami nadprzyrodzonymi może być uznana za próbę duchowego samookreślenia i wyraz rozterek dręczących człowieka na progu nowoczesności.

Słowa kluczowe: Huysmans, Reymont, psychika, podświadomość, nowoczesność, ezoteryka

W słynnej „satanistycznej” powieści Jorisa-Karla Huysmansa, Là-bas, znajduje się symboliczna scena. Oto Durtal, uczony-artysta, który przygotowuje rozprawę o życiu średniowiecznego zbrodniarza, Gillesa de Rais, wspina się w nieprzeniknionych ciemnościach na wieżę paryskiego kościoła Saint-Sulpice. Spotka tam dzwonnika Carhaix, z którym toczyć będzie dysputy na temat mrocznych labiryntów kultu szatana, zaludnianych w czasach autora $L \grave{a}$-bas przez rzesze nowych wyznawców. Huysmans opóźnia moment, gdy jego bohater zapuka 
wreszcie do drzwi mieszkania Carhaix, położonego wysoko ponad dachami dziewiętnastowiecznego Paryża. Durtal zatrzymuje się bowiem na pogrążonych w mroku schodach, by spojrzeć kolejno w górę i w dól. Doznaje nagle zawrotu głowy: jego oczom ukazują się „dwie otchłanie [...] podwójna studnia, z których jedna ziała głębią pod jego stopami, a druga wznosiła się nad nim" ${ }^{1}$. Durtal tkwi więc jakby w nieruchomym punkcie, pośrodku świata, między dwiema lustrzanymi przepaściami i tylko od niego zależy, w którą stronę się zwróci. Mógłby śmiało powtórzyć za Charlesem Baudelairem: „Na dole - w górze - wszędzie - tylko głębie ciemne - / Milcząca czarna otchłań, co mą duszę trwoży!"2.

Mroki Baudelairowskiej przepaści, która zieje pustką, przerażają też Zenona, głównego bohatera Wampira Władysława Stanisława Reymonta. O ile Huysmans każe Durtalowi zatrzymać się, by mógł w przebłysku świadomości zajrzeć w zwierciadło odbijające tajemniczą, podwójną naturę świata i człowieka, o tyle u Reymonta bohater wciąż pozostaje w ruchu. Ruch ten wydaje się jednak jałowy - Zenon błądzi bowiem po zamglonym Londynie, a w tym chaotycznym błądzeniu otchłanie osaczają go powoli i nieustępliwie. Najpierw bohater Reymonta uświadamia sobie prawdę o mieście nad Tamizą, do którego rzucił go nieprzenikniony los: „Londyn podczas mgły to otchłań, łatwo można się zgubić

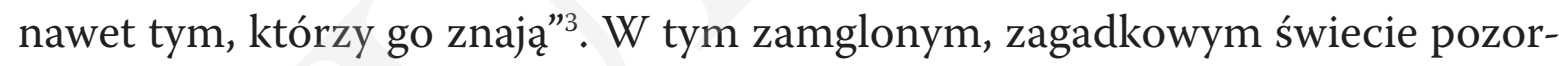
ne i nietrwałe okazują się wszystkie zdobycze racjonalnej cywilizacji Zachodu, przeciwstawione uduchowionej nauce hinduskiego mędrca, Mahatmy Guru Myśl europejska jawi się Zenonowi jako efemeryczna budowla, wzniesiona nad otchłanią tajemnicy:

Cóż wiemy? Nic. Utonęliśmy w głupich, nic nie tłumaczących faktach, których się trzymamy jak poręczy nad przepaściami, nie śmiejąc poruszyć się z miejsca, ba, pomyśleć nawet, że można się rzucić w otchłań i nie zginąć... nie przepaść... a właśnie tam znaleźć tę jedyną prawdę, duszę własną! ${ }^{4}$.

W końcu bohater Reymonta odkrywa ciemne głębie we wnętrzu samego siebie: „Nie ma nic bardziej przerażającego nad usuwanie się świadome w prze-

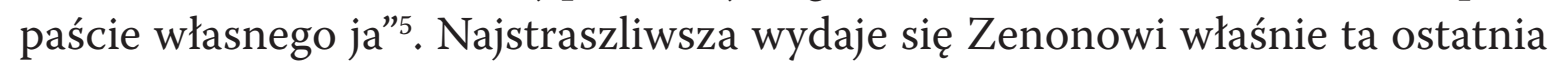
otchłań - ludzka dusza. W Wampirze na pierwszy plan wysuwa się bowiem

${ }^{1}$ J.-K. Huysmans, Là-bas, oprac. Y. Hersant, Paris 2006, s. 55.

2 Ch. Baudelaire, Otchtań, przeł. A. Lange, [w:] tegoż, Kwiaty zła, oprac. M. Jastrun, Warszawa 1973, s. 130.

3 W. S. Reymont, Wampir, Kraków 2003, s. 35.

4 Tamże, s. 55.

5 Tamże, s. 103. 
człowiek, jego nieraz sprzeczne pragnienia i emocje. Tym samym Reymont zwraca się ku wnętrzu, penetrując nieznane pokłady psychiki człowieka. Nowoczesność tematyki Wampira na tle dokonań ówczesnej literatury eksponuje Jerzy Krzyżanowski: „Reymont wyruszył na badanie nieznanych terytoriów w psychice ludzkiej. Zwracając swe zainteresowanie ku psychologii i patologii, wskazał on nowe drogi wielu współczesnym pisarzom"6.

Paradoksalnie, Reymont - pisarz zgoła nieawangardowy - spotyka się w tym miejscu z przedstawicielami młodszego pokolenia, takimi jak choćby Karol Irzykowski, prefreudowski badacz "garderoby duszy” i podziemnego życia psychicznego ${ }^{7}$. Ada, dawna ukochana Zenona, znajduje na przykład mroczną otchłań tam, gdzie nie dociera świadoma myśl:

Mnie się zdaje, że poza kręgiem naszej świadomości rozciąga się straszliwa przepaść, w której kłębią się przerażające potwory, jakieś tajemnicze byty i larwy zgoła niepojęte! A kto, raz uwiedziony ciekawością, zajrzy na to dno, musi być zgubiony! Ja głęboko wierzę w Boga, kocham słońce i jasny dzień, kocham życie i bardzo się lękam wszystkiego, co nie jest z tego świata!

W tym kontekście niesamowite fenomeny, których doświadcza Zenon, można uznać po prostu za projekcje jego podświadomości. Jak pisze Dariusz Trześniowski: „Pozbawiony luster identyfikacji, usankcjonowanych przez tradycję aksjologicznych układów odniesienia, rozpada się człowiek, gubi swą tożsamość, odkrywając w sobie złowrogie mare tenebrarum [...]"

Centralnym punktem świata przedstawionego w Wampirze, a także spiritus movens całej akcji, jest główny bohater. Można by nawet zaryzykować stwierdzenie, że cała powieść „dzieje się” niejako we wnętrzu Zenona, ujawniając po prostu jego duchowe rozterki i problemy. Stąd dużo monologów wewnętrznych oraz fragmentów opisowych, mających cechy mowy pozornie zależnej. Bohater Reymonta ogląda otaczający go świat przez pryzmat swojego wewnętrznego rozdarcia między ojczyzną a krajem, w którym przyszło mu żyć, jawą a snem, Wschodem a Zachodem, żądzą a intelektem, szaleństwem a zdrowym rozsądkiem. Zainteresowanie mediumizmem, zwrot ku nieznanemu jest w jego przypadku próbą znalezienia odpowiedzi na pytanie o własną konstrukcję psychiczną

${ }^{6}$ J. Krzyżanowski, „Marzyciel” i „Wampir”, [w:] tegoż, Legenda Samosierry i inne prace krytyczne, Warszawa 1987, s. 48.

7 Zob. K. Irzykowski, Patuba, [w:] Pałuba. Sny Marii Dunin, Kraków 1976, s. 211-219.

8 W. S. Reymont, dz. cyt., s. 159-160.

9 D. Trześniowski, „Wampir” Reymonta: upiorne sny zmęczonej Europy, [w:] Inny Reymont, pod red. W. Książek-Bryłowej, Lublin 2002, s. 117. 
i o swoje miejsce w świecie. Próba ujarzmienia chaosu rzeczywistości musi się zacząć od uporządkowania własnego wnętrza. Zenon może być zatem uznany za uosobienie człowieka konfrontującego się z kiełkującą w czasach Reymonta nowoczesnością i za porte-parole samego pisarza, który na przełomie stuleci wyrażał niepokoje swojej epoki. Według Georga Simmla, autora jednej z pierwszych definicji nowoczesności, jej istotą

jest psychologizm; przeżywanie (das Erleben) i interpretowanie świata w kategoriach reakcji naszego życia wewnętrznego, a zatem faktycznie jako świata wewnętrznego; rozpad stałych treści w płynnym pierwiastku duszy, w który przemienia się wszystko, co substancjalne, a którego formy są po prostu formami ruchu ${ }^{10}$.

Nowoczesne są także tematyka i konstrukcja Huysmansowskiego Là-bas, na co już w 1898 roku zwracał uwagę Paul Valéry:

Doszliśmy szybko do wyeliminowania wszelkiej akcji. Dialog, rygorystycznie uproszczony, ograniczył się do wymiany słów, zapisanych lub sfabrykowanych przez autora, i od tej pory nie daje nic poza odtworzeniem schematu realnych rozmów, różnych głosów i opinii ${ }^{11}$.

W Là-bas przemawia w rzeczywistości jedna osoba - sam autor. Rémy de Gourmont pisał o twórczości Huysmansa: „W jego książkach zawsze się coś dzieje: dzieje się on sam [tłum. aut.]"12. Durtal (podobnie jak Zenon) może być uznany za jedną z masek, które nakłada pisarz. Na taką interpretację wskazywałaby także wyraźna paralelność duchowej drogi Huysmansa i jego bohatera. Durtal porusza się w sztucznym świecie książek. Poczucie sztuczności świata ma również twórca Là-bas, świadomie zacierający granice między tym, co obiektywne a subiektywnymi sądami. Dlatego Huysmans miesza swobodnie materiał historyczny z autobiografią duchową i wytworami fantazji, a w jego powieści kanonik Docre, duchowny-odszczepieniec, przywódca fikcyjnej sekty dziewiętnastowiecznych wyznawców Szatana, wydaje się postacią równie rzeczywistą co Gilles de Rais. Pisarz prowadzi również intertekstualny dialog ze swoim własnym dziełem. Stąd w Là-bas możemy znaleźć między innymi odwołania do słynnej

${ }^{10}$ Cyt. za: R. Nycz, Literatura jako trop rzeczywistości. Poetyka epifanii w nowoczesnej literaturze polskiej, Kraków 2001, s. 21.

11 P. Valéry, Préface, [w:] J.-K. Huysmans, Le roman de Durtal, Paris 1999, s. 9.

12 R. de Gourmont, Promenades littéraires; cyt. za: G. Bonnet, «Là-bas » de Joris-Karl Huysmans, Paris 2004, s. 140. 
"Biblii dekadentów” - Na wspak. Oto zbrodniarz z Tiffauges jest po prostu „Des Esseintesem piętnastego wieku"13. Można więc uznać, że Huysmans antycypuje w jakiś sposób tezy dwudziestowiecznych pisarzy i badaczy literatury, którzy uznawali, że nie istnieje nic poza tekstem ${ }^{14}$.

Zdaniem Teresy Walas, Durtal to literacka prezentacja osobowości dekadenckiej. Badaczka zauważa, że Huysmans wybiera bohatera statycznego i biernego, co sprawia, że opowiadana historia nieuchronnie zmierza ku fabularnemu bezruchowi:

To powoduje i umożliwia zarazem rozluźnienie struktury powieści: wyhamowanie biegu fabuły i przyznanie jej roli pretekstu, wprowadzenie kompozycji epizodowej i dywagacyjnej. Powieść zwalnia tempo i traci spoistość, zbliża się do eseju, rozprawy filozoficznej, traktatu, często zawiera w sobie kompozycyjnie wyodrębnione mikrotraktaty czy mikroeseje o sztuce ${ }^{15}$.

W ten sposób bohater staje się centrum powieściowego świata, a narracja zyskuje cechy wewnętrznej i personalnej. Durtal, tak jak Reymontowski Zenon, obserwuje bowiem rzeczywistość przez pryzmat samego siebie i w kontekście literatury. W jego literackim świecie podróż do krainy zła to w gruncie rzeczy spojrzenie w głąb własnej duszy. W powieści Huysmansa roi się od monologów wewnętrznych, a jego zmęczony bohater stawia wciąż pytania, na które nie ma odpowiedzi. Zdaniem Yvesa Hersanta, formuła tytułowa Là-bas odsyła zarówno do świata znajdującego się poniżej, jak i do świata wewnętrznego (po francusku gra słów - inférieur/intérieur $)^{16}$. W tym kontekście metafizyczne spacery Durtala mogą być uznane za autoanalizę, próbę zdobycia samoświadomości. W realistycznym planie powieści mamy przecież do czynienia z zaledwie kilkoma miejscami akcji, wśród których trzeba wymienić: mieszkanie Durtala, mieszkanie Pani Chantelouve, opuszczoną kaplicę, a przede wszystkim siedzibę dzwonnika Carhaixa, która stanowi tło dla wszystkich najważniejszych dyskusji, jakie przenoszą czytelnika w makabrę średniowiecza oraz w sięgający tej epoki (ale wciąż żywy w czasach Huysmansa) mroczny kult Szatana. Świat mentalny, który wyłania się z dialogów, dominuje więc nad rzeczywistym. Wydaje się wręcz, że słowa Huysmansowskich bohaterów mają jakąś moc sprawczą. Kreują

13 J.K. Huysmans, dz. cyt., s. 74.

14 Zob. np. R. Nycz, Tekstowy świat. Poststrukturalizm a wiedza o literaturze, Warszawa 1995, s. 71-75.

15 T. Walas, Ku otchłani (dekadentyzm w literaturze polskiej 1890-1905), Kraków 1986, s. 98.

16 Zob. Y. Hersant, Préface, [w:] J.K. Huysmans, dz. cyt., s. 12. 
bowiem nową duchową przestrzeń, w której teraźniejszość miesza się z przeszłością, a twory wyobraźni i fakty historyczne stanowią nierozerwalną całość. Jest to świat duszy, w którym nie obowiązują prawa logiki, a prawda literatury wypiera prawdę życia.

Huysmans i Reymont głęboko odczuwali kryzys dawnego obrazu świata, zakorzenionych w kulturze koncepcji człowieka i tradycyjnych, opartych na religii, systemów wartości. W ich prozie można dostrzec interesujący zapis doświadczenia nowoczesności. Przeczucie, nadchodzących wielkimi krokami zmian, widać w całym świecie przedstawionym Là-bas i Wampira, a także w warstwie językowej tych powieści. W przedmowie do Paryskiego spleenu Baudelaire stwierdza, że nowoczesne życie wymaga nowego języka: „prozy poetyckiej, muzycznej bez rytmu i rymu, dość giętkiej i skontrastowanej, aby mogła oddać liryczne drgnienia duszy, falowanie marzeń, skoki świadomości”17. Język Huysmansa, hermetyczny i wyrafinowany, zdaje się doskonałym narzędziem do opisu świata, który zatracił kartezjańską jasność i przestał być zrozumiały. Bohaterowie Là-bas żonglują trudnymi pojęciami, w ich ciasnych granicach starają się zamknąć swą wiedzę zarówno o minionych epokach, jak i o czasach współczesnych oraz przyszłości. Oniryczna konwencja Wampira odzwierciedla zaś zacieranie się granic między snem a jawą: „I tak zapomnieli o wszystkim, że nikt już nie wiedział, rzeczywistość to - li sen czarowny?"18. Język Reymonta zbliża się w tej powieści do postulowanej przez Baudelaire'a muzycznej prozy poetyckiej, w której cisza rozbrzmiewa szeptami. Metaforyka Wampira odwołuje się zaś przede wszystkim do sfery śmierci i rozkładu. W opisach Londynu powraca wciąż motyw konania: oto „rozchwiane kontury drzew" przypominają „trupy” ${ }^{\prime 19}$, mury są „strupieszałe” ${ }^{20}$, a hałas codziennego życia nasuwa na myśl "głosy grobów”21; angielskie domy stoją „martwym szeregiem”22, są „brudne, niby przegniłe trumny, rojące się ludzkim robactwem”" Wstający nad Londynem świt kojarzy się Reymontowi z „martwą jasnością”, w której „gwiazdy zamierały jak oczy przysłaniane martwiejącymi powiekami”24. Smutek miasta przekłada się więc na melancholię całego świata, która dotyka dusz bohaterów „przegniłymi trupimi rękami”25. Według Beaty Utkowskiej: „narracja personalna,

${ }_{17}$ Ch. Baudelaire, Do Arsena Houssaye, [w:] tegoż Paryski spleen. Poematy proza, przeł. J. Guze, Warszawa 1992, s. 6.

18 W.S. Reymont, dz. cyt., s. 7.

19 Tamże, s. 88.

20 Tamże, s. 89.

21 Tamże.

22 Tamże, s. 53.

${ }^{23}$ Tamże, s. 170.

${ }^{24}$ Tamże, s. 96.

${ }^{25}$ Tamże, str. 136. 
poetyka krzyku i technika oniryczna [...] sygnalizują kierunek zmian zachodzących w dwudziestowiecznej prozie pod wpływem surrealizmu"26. Tą prekursorską rolę zapomnianego utworu polskiego noblisty podkreśla także Krzyżanowski: „Reymont zupełnie właściwie przewidział nowe kierunki powieści psychologicznej naszego stulecia"27.

Zarówno w Là-bas, jak i w Wampirze, akcja toczy się przede wszystkim w psychice głównych bohaterów. Obraz rzeczywistości staje się w tych powieściach projekcją wewnętrznych przeżyć, obaw i lęków postaci, które uosabiają rozterki człowieka końca dziewiętnastego wieku. Co więcej, można zaryzykować stwierdzenie, że Durtal i Zenon to artyści, którzy próbują wypracować zasady nowej sztuki - są pisarzami. Obaj przeżywają dotkliwie kryzys duchowy epoki i mają świadomość, że tradycyjne narzędzia poznania nie wystarczają już człowiekowi przełomu stuleci. Należy jednak zauważyć, że podczas gdy Reymont w Wampirze zupełnie porzuca realistyczną formułę i wprowadza do swojego tekstu zjawiska nadprzyrodzone, bohaterowie Huysmansa nie mają bezpośrednio do czynienia z nadzmysłowymi fenomenami, które pojawiają się tylko w ich rozmowach. Autor Là-bas, wierny swoim literackim korzeniom, pozostał więc w jakimś stopniu naturalistą, tak jak jego bohater, który o tym, co nadprzyrodzone, tylko mówi i słyszy, osobiście nigdy nie doświadczając niesamowitej, ciemnej strony istnienia. Badacze twórczości Huysmansa zwracają uwagę, że w trakcie pracy nad powieścią zachowywał się jak na ucznia Emila Zoli przystało - zbierał materiały, studiował stare księgi, szukał wiarygodnych źródeł, jednym słowem dbał, żeby jego książka była jak najbardziej prawdziwa ${ }^{28}$. Zaskakujące jest to, że pisarz zdecydował się ująć w ramy powieści realistycznej temat, który realizmowi zdecydowanie się wymykał; metoda jego pracy pozostawała przy tym konsekwentnie racjonalistyczna ${ }^{29}$. Obrazem tej sprzeczności jest główny bohater Là-bas, Durtal, który powtarza drogę Huysmansa, próbując zrozumieć to, co z definicji musi pozostać niepojęte.

Huysmans potrafił przezwyciężyć własną fascynację zjawiskami nadnaturalnymi i wiarę w interwencje tajemniczych sił w codzienną, pospolitą rzeczywistość, zachowując w swej powieści zdystansowany stosunek obiektywnego obserwatora. Warto przypomnieć, że pisarz uczestniczył w seansach spirytystycznych i traktował je zawsze ze śmiertelną powagą ${ }^{30}$. W przypadku Reymonta, który także brał

${ }^{26}$ B. Utkowska, Poza powieścia. Małe formy epickie Reymonta, Kraków 2004, s. 204.

27 J. Krzyżanowski, dz .cyt., s. 48.

28 Zob. G.Bonnet, dz.cyt., s. 51-54; por. też M.L. Issaurat-Deslaef, Là-bas: logique et signification du fantastique, [w:] „Bulletin de la Société J.K. Huysmans” 1978, nr 69, s. 28.

29 Zob. M.L. Issaurat-Deslaef, dz. cyt., s. 28.

30 Zob. R. Baldick, The Life of J.K. Huysmans, Langford Lodge 2006, s. 202. 
udział w mediumicznych eksperymentach, widać zaś osobiste zaangażowanie pisarza w przedstawione wydarzenia. W Wampirze brak autorskiego dystansu, co w pewnej mierze obniża walory artystyczne tej powieści. Być może znaczące są tu role, jakie każdy z pisarzy odgrywał przy wirującym stoliku: Huysmans zasiadał tam na prawach zwykłego uczestnika, Reymont nie raz służył zgromadzonym za medium. Dlatego autor Là-bas (podobnie jak jego bohater) potrafi zdobyć się na dystans badacza-obserwatora, podczas gdy Zenon, literackie alter ego Reymonta, zdaje się niejako prokurować niesamowite fenomeny. Znaczący jest tu opis czarnej mszy, w której uczestniczą bohaterowie obu powieści. U Huysmansa, jak na adepta naturalizmu przystało, relacja z ceremonii przy rue de Vaugirard jest rzeczowa i chłodna. Początkowo Durtal z przenikliwością naukowca analizuje to, co widzi, posługując się przy tym fachowym słownictwem. Ów znawca katolickiej liturgii bierze czarną mszę za zwykłą mszę bez śpiewu (messe basse ${ }^{31}$ ). Później, kiedy bluźniercza ceremonia przekształca się stopniowo w wyuzdaną orgię, bohater Huysmansa, „przepełniony odrazą, niemal zaczadzony” („excédé de dégoût, a moitié asphyxié") ${ }^{32}$, po prostu wychodzi.

W przeciwieństwie do autentycznej rue de Vaugirard - najdłuższej ulicy współczesnego Paryża - grota - stanowiąca tło dla czarnej mszy w Wampirze - sytuuje się gdzieś pomiędzy jawą a snem. Zenon nie może po prostu opuścić tego miejsca - tkwi w nim wbrew swojej woli, jakby przykuty niewidzialnym łańcuchem, i doświadcza niezwykłych wizji:

[...] pochylił się w sobie, jakby nad krawędzią świata nieznanego, spoglądał w tajemnice i jego oczy duszy pierwszy raz wybiegły poza siebie, poza głupią i leniwą myśl, poza fakty i rzeczy widome; pierwszy raz leciały przez jakieś nieprzejrzane obszary, przez jakieś dale czarowne, przez jakieś wyże i przepaście nieskończone, iż cofnął się olśniony, pełen świętej cichości przeczuwań i widzeń, jakiś wiew nieśmiertelnej mocy przewiał mu przez duszę ${ }^{33}$.

Warto zwrócić uwagę na to, że opis wewnętrznych przeżyć Zenona zbliża się - przez rozbicie logicznych powiązań pomiędzy kolejnymi sekwencjami tekstu - do automatycznego pisania surrealistów lub strumienia świadomości, z którym eksperymentowano już u schyłku dziewiętnastego wieku ${ }^{34}$. Podobne

31 J.K. Huysmans, dz. cyt., s. 293.

32 Zob. tamże, s. 297.

33 W.S. Reymont, dz. cyt., s. 95.

${ }^{34}$ Elementy takiej techniki można dostrzec np. w opowiadaniu Édouarda Dujardina Wawrzyny już ścięto (1888). 
spostrzeżenia czyni Danuta Knysz-Tomaszewska w swoim artykule na temat opowiadań fantastycznych Reymonta, zastrzegając jednak, że trudno uznać go za przedstawiciela awangardy: „Nie jest to jeszcze automatyczne pisanie, które postulować będą surrealiści, zafascynowani techniką sennych obrazów, ale epicka narracja we wszystkich prezentowanych tu tekstach ulega rozsadzeniu"35.

Człowiek u progu nowoczesności, tak jak Huysmansowski Durtal, znajduje się między dwiema przepaściami. Swój wzrok może skierować zarówno w górę, jak i w dól, w stronę jasną lub ciemną, ale pociąga go przede wszystkim to, co zakazane, co prowadzi ku otchłani moralnego piekła. Jeśli nie jest tego w pełni świadom, przynajmniej to przeczuwa. Rozdarty między lękiem a fascynacją, niepewnością a odwagą, balansuje na cienkiej linie, poszukując rozpaczliwie równowagi - jak stary linoskok Baudelaire'a czy linoskoczek Nietzschego, linoskok balansujący nad otchłanią, prefiguracja tego, co niedługo nastąpi - koszmarów dwudziestego stulecia.

U Huysmansa i Reymonta nietrudno dostrzec motyw lęku przed nowoczesnością. Là-bas kończy się surową krytyką nowoczesnego społeczeństwa, a bohater powieści - po chwili wahania - nieuchronnie podąży w szeroko otwarte ramiona tradycyjnego Kościoła, w przeszłość, w średniowieczny splendor chrześcijańskich rytuałów. Ale o tym dowiemy się dopiero z kolejnego tomu cyklu - $W$ drodze. Nieco inne jest zakończenie Wampira: wyzwoliwszy się spod jarzma religii i zachodniej moralności, doznawszy rozpusty, bluźnierstwa i zła, Zenon odkrywa jedyną drogę: „A choćby nawet Szaleństwo i Śmierć!”36. Nie przypadkiem okręt, który uwozi go w nieznane, nosi imię symbolicznego potwora, szekspirowskiego Kalibana, nieszczęsnej bestii pożądającej wolności za wszelką cenę.

Fascynację ezoteryką, której świadectwem są powieści Huysmansa i Reymonta, można uznać za próbę odpowiedzi na pytania dręczące człowieka na progu nowoczesności. Zainteresowanie zjawiskami nadprzyrodzonymi odzwierciedla dążenie do duchowego samookreślenia. Granice ludzkiego poznania determinują świat, ponieważ obraz rzeczywistości zawiera się w poznającym ją podmiocie. Szukając prawdy o bycie, musimy więc przede wszystkim szukać prawdy o sobie. Wiedzieli to Huysmans i Reymont, owi voyageurs en eux-mêmes - podróżnicy w głąb samych siebie, by posłużyć się formułą, przywołaną przez Huysmansa w jego osobistych notatkach, zwanych Carnet vert ${ }^{37}$. Durtal i Zenon za sprawą ezoteryki schodzą więc là-bas w poszukiwaniu wampirycznej wiedzy o nich

35 D. Knysz-Tomaszewska, W stronę niepoznawalnego. Nowele Reymonta w kontekście opowiadań fantastycznych Guy de Maupassanta, [w:] Inny Reymont, dz. cyt., s. 36.

36 W.S. Reymont, dz. cyt., s. 177.

37 Zob. G. Bonnet, dz. cyt., s. 141. 
samych, żywią się własnym bytem, czując zarazem, że słabną i umierają. Samotni w swoich mentalnych wędrówkach, przemierzają otchłanie nieba i piekła, nie ruszając się z miejsca. Poszukujący i wolni, stają wreszcie na progu tajemnicy. Mogą się jeszcze zatrzymać (jak Durtal), ale otchłań wabi szaleństwem i śmiercią, które obiecują ukoić „trującymi jadami niepokojów, obaw i niepewności”38. Przy wtórze cicho pracujących maszyn „Kalibana”, Zenon podejmuje decyzję: "Raczej śmierć niźli takie życie, niźli to niewolnicze, pełzające bytowanie robaków wśród cierpień, strachów i ciemności... [...] ...a przed świtem «Kaliban» wypłynął z portu w nieznanym kierunku” ${ }^{39}$.

\section{Bibliografia}

Baldick R., The Life of J.K. Huysmans, Langford Lodge 2006.

Baudelaire Ch., Do Arsena Houssaye, [w:] tegoż Paryski spleen. Poematy proza, przeł. J. Guze, Warszawa 1992.

Baudelaire Ch., Otchłań, przeł. A. Lange, [w:] tegoż, Kwiaty zła, oprac. M. Jastrun, Warszawa 1973.

Bonnet G., « Là-bas » de Joris-Karl Huysmans, Paris 2004.

Huysmans J.-K., Là-bas, oprac. Y. Hersant, Paris 2006.

Irzykowski K., Pałuba, [w:] Pałuba. Sny Marii Dunin, Kraków 1976.

Issaurat-Deslaef M.-L., Là-bas: logique et signification du fantastique, [w:] „Bulletin de la Société J.K. Huysmans" 1978, nr 69.

Knysz-Tomaszewska D., W stronę niepoznawalnego. Nowele Reymonta w kontekście opowiadań fantastycznych Guy de Maupassanta, [w:] Inny Reymont, pod red. W. Książek-Bryłowej, Lublin 2002.

Krzyżanowski J., „Marzyciel” $i$,Wampir”, [w:] tegoż, Legenda Samosierry i inne prace krytyczne, Warszawa 1987.

Nycz R., Literatura jako trop rzeczywistości. Poetyka epifanii w nowoczesnej literaturze polskiej, Kraków 2001.

Nycz R., Tekstowy świat. Poststrukturalizm a wiedza o literaturze, Warszawa 1995.

Reymont W. S., Wampir, Kraków 2003.

Trześniowski D., „Wampir” Reymonta: upiorne sny zmęczonej Europy, [w:] Inny Reymont, pod red. W. Książek-Bryłowej, Lublin 2002.

Utkowska B., Poza powieścia. Małe formy epickie Reymonta, Kraków 2004.

Valéry P., Préface, [w:] J.-K. Huysmans, Le roman de Durtal, Paris 1999.

Walas T., Ku otchtani (dekadentyzm w literaturze polskiej 1890-1905), Kraków 1986.

38 W.S. Reymont, dz. cyt., s. 177.

39 Tamże, s. 176-177. 
Summary: The author confronts two important modernist novels: Là-bas by Joris-Karl Huysmans (1891) and Wampir by Władysław Stanisław Reymont (1911). Apparently entirely different, these works reveal however the similarity of themes and ideas. Both in Là-bas and Wampir the action takes place in the psyche of main characters. As a consequence an external world reflects their soul. An important context of an analysis of both novels refers to the modernity which determines all the interpretatations. In case of Wampir novel's qualities are depreciated by a lack of the author's distance from supernatural phenomena which fascinate his hero. As far as Là-bas is concerned, although Huysmans was deeply interested in esotericism, at the same time he was able to achieve the necessary distance from his story. Due to that Là-bas represents an exceptional literary value. Both in Là-bas and Wampir the fascination with supernatural phenomena might be considered as an attempt of a spiritual self-determination and an expression of dilemmas which torment the human on the verge of modernity.

Keywords: Huysmans, Reymont, psyche, subconciousness, modernity, esotericism 